\title{
BENTUK-BENTUK DIGITAL SIGNATURE YANG SAH DALAM TRANSAKSI ELEKTRONIK DI INDONESIA
}

Oleh:

\author{
I Wayan Ariadi ${ }^{1}$
}

\begin{abstract}
Information technology has become one of Indonesian law's issues because of the security in information systems that influence the course of electronic transactions, so that it is necessary to put signatures on electronic transactions to ensure validity just like some paper basis transactions. The purpose of this study was to determine the forms of digital signatures in any electronic transactions are legitimate. This journal writing is done by using normative method. Signature that can guarantee an electronic transaction so that it can become legal evidence is an electronic or digital signature, forms of electronic signatures is password; scanned signatures or typed names; ok button or the accept button; biometric; and the use of other electronic signature of a messagebased encryption (digital signature).
\end{abstract}

Keywords: Information Technology, Electronic Transactions, Signature

\begin{abstract}
Abstrak
Teknologi informatikamenjadi salah satu isu hukum di Indonesiakarenakeamanan sistem informasi mempengaruhi jalannya transaksi elektronik, sehingga perlu untuk menempatkan tanda tangan pada transaksi elektronik unutk memastikan validitas seperti beberapa transaksi secara kertas. Tujuan dari peneletian ini adalah untuk menentukan bentuk tanda tangan digital dalam transaksi elektronik adalah sah. Penelitian jurnal ini dilakukan dengan menggunakan metode normatif. Tanda tangan yang dapat menjamin transaksi elektronik sehingga bias menjadi bukti hukum adalah tanda tangan elektronik atau digital, bentuk tanda tangan elektronik adalah password; scan tanda tangan atau diketik naman; tombol ok atau tombol menerima; biometrik; dan penggunaan tanda tangan elektronik lainnya dari enkripsi berbasis pesan (tanda tangan digital)
\end{abstract}

Kata Kunci : Teknologi Informasi, Transaksi Elektronik, Signature.

\section{PENDAHULUAN}

\subsection{Latar Belakang}

Transaksi elektronik akan

menyebabkan seseorang memasuki dunia maya yang bersifat abstrak, universal, serta lepas dari keadaan tempat dan waktu melalui media elektronik. ${ }^{2}$ Keberadaan metode atau sistem autentikasi dari suatu informasi elektronik yang disampaikan dalam suatu transaksi elektronik menjadi kunci legalitasnya suatu transaksi

\footnotetext{
Mahasiswa Magister Ilmu Hukum Universitas Udayana, Denpasar, Bali. Alamat Jl. Hayam Wuruk Nomor.66 Denpasar, e-mail: aryadiputra_ajus@yahoo.com

2 Mariam Darus Badrulzaman, 2001, Mendambakan Kelahiran Hukum Saiber (Cyber Law) di Indonesia, Purna Bhakti, Medan, hlm. 3.
} 
elektronik. Lazimnya, tanda tangan merupakanmetodekonvensionaldalam menentukan sahnya suatu informasi yang digunakan dengan berbasiskan kertas. Secara hukum, keberadaaan tanda tangan tersebut akan digunakan sebagai bukti yang sah dari kebenaran atas informasi tersebut, sehingga setiap penggunaan tanda tangan berarti merepresentasikan adanya suatu keautentikan dan originalitas dari suatu dokumen atau informasi, tidak hanya transaksi yang berbasis kertas namun juga elektronik.

Teknologi informasi saat ini telah menjadi persoalan hukum dikarenakan perihal pengamanan dalam sistem informasi itu sendiri masih perlu dipertanyakan. Tanpa pengamanan yang ketat dan canggih, perkembangan teknologi informasi di Indonesia tidak akan dapat memberikan manfaat yang maksimal bagi masyarakat.

\subsection{Perumusan Masalah}

Berdasarkanuraianlatarbelakang diatas, maka penulis merumuskan permasalahan sebagai berikut :

1. Bagaimanakah Pengaturan Transaksi Elektronik di Indonesia?

2. Bagaimanakah bentuk tanda tangan yang sah digunakan dalam transaksi elektronik di indonesia?

\subsection{Tujuan Penelitian}

Penelitian ini secara umum bertujuan untuk memahami dan menganalisa pengaturan transaksi secara elektronik di Indonesia seluruh masyarakat Indonesia dapat melakukan transaksi elektronik secara aman dan bertanggungjawab. Sedangkan yang menjadi tujuan khusus adalah :

1. Untuk mengkaji dan menganalisa pengaturan transaksi elektronik di Indonesia.

2. Untuk menganalisa dan mensistematisasi bentuk-bentuk tanda tangan dalam transaksi elektronik sebagai suatu alat bukti yang sah.

\section{METODE PENELITIAN}

Metode penelitian yang digunakan dalam penulisan ini adalah metode penelitian hukum normatif (analisis normatif) karena mempergunakan bahan-bahan kepustakaan sebagai sumber data penelitian. ${ }^{3}$ Oleh karena jurnal ini merupakan penelitian hukum normatif, maka data diperoleh melalui data yang telah diteliti dan dikumpulkan oleh pihak lain yang berkaitan dengan permasalahan penelitian. ${ }^{4}$

III. HASIL DAN PEMBAHASAN

3.1. Informasi dan Transaksi Elektronik di Indonesia dari Sudut Pandang Lapisan Ilmu Hukum.

Globalisasi informasi beserta dampaknya telah menempatkan

Amiruddin dan Zainal Asikin, 2004, Pengantar Metode Penelitian Hukum, PT. Raja Grafindo Persada, Jakarta, hlm. 166.

Bambang Sunggono, 2010, Metodologi Penelitian Hukum, Rajawali Pers, Jakarta, hlm. 86. 
Indonesia sebagai suatu bagian dari masyarakat informasi dunia, sehingga mengharuskan dibentuknyapengaturan mengenai pengelolaan Informasi dan Transaksi Elektronik. Urgensi pengaturan informasi dan transaksi elektronik berpijak pada refleksi terhadap kebutuhan praktik yang terjadi di era globalisasi. Refleksi terhadap sebuah peristiwa hukum bukanlah semata-mata berada pada ranah yuridis empiris, melainkan menekankan pada alasan-alasan mengapa hukum atau peraturan mengenai informasi dan transaksi elektronik tersebut harus dibentuk yang diperkuat dengan landasan filosofis, yuridis, dan sosiologis. Kajian mengenai Filsafat merefleksi merupakan Dalil Filsafat Hukum (Meuwissen) yang berpijak pada refleksi terhadap masalah dan persoalan dalam kehidupan masyarakat yang termasuk dalam bidang hukum, dalam hal ini terkait dengan pengaturan informasi dan transaksi elektronik yang memusatkan perhatiannya khusus pada gejala hukum, dan titik akhirnya menghasilkan sebuah pengaturan yang memiliki legalitas.

Filsafat merupakan suatu tindakan berpikir secara cermat dan hati-hati terhadap suaru gejala yang terjadi di masyarakat. Mempelajari filsafat sama halnya dengan mencari hakikat atau landasan dari gejala-gejala yang lebih dalam serta ciri khasnya. Yang terpenting adalah setiap dalil filsafat harus dibuat dan dipahami secara rasional (terargumentasikan). Filsafat bukanlah kepercayaan atau dogmatika. Kepercayaan adalah menerima begitu saja suatu pendirian atas dasar kewibawaan seseorang, sedangkan filsafat tidak demikian dan harus berdasarkan pada argumentasi rasional. Berdasarkan argumentasi yang rasional, mengartikan bahwa penalaran-penalaran filsafat harus sah secara logika serta dalam pemilihan premis maupun kesimpulan harus selalu terbuka bagi suatu bantahan rasional dalam dialog intersubyektif yang mana kebenaran dapat dan harus ditemukan. Hal ini berarti bahwa filsafat tidak bersifat dogmatika (kaku atau ketiadaan toleransi). ${ }^{5}$

Terdapat tiga tataran abstraksi refleksi teoretikal atas gejala hukum, yakni ilmu hukum, teori hukum, dan filsafat hukum. Filsafat hukum berada pada tataran tertinggi dan meresapi semua bentuk pengembanan hukum teoritikal dan pengembanan hukumpraktikal. Dalam menganalisis pengaturan mengenai pengaturan informasi dan transaksi elektronik di Indonesia pada tingkatan tertinggi lapisan ilmu hukum dengan berpijak pada kajian-kajian filslafat untuk menemukan hakikat kebenaran dan keadilan yang diintegrasikan pada nilai-nilai dasar peraturan antara lain nilai keadilan, kepastian, dan kemanfaatan. Nilai-nilai tersebut akan diformulasikan dalam tatanan keilmuan yang lebih konkrit yakni

Arief Sidahrta, 2007, Meuwissen, tentang Pengembangan Hukum, Ilmu hukum, teori hukum, Filsafat Hukum, Refika Aditama, Bandung. 
dalam ranah dogmatika hukum yang terumuskan dalam pasal-pasal hukum positif informasi dan transaksi elektronik di Indonesia. Dari sudut pandang ilmu perundang-undangan, sebuah peraturan perundang-undangan yang baik sendiri haruslah dibuat berdasarkan tiga asas, yaitu asas yuridis, sosiologis dan filosofis. ${ }^{6}$

Hal ini berarti bahwa logika tradisional dari cara berpikir positifistik yang menempatkan lembaga yang berwenang sebagai subyek hukum dan anggota masyarakat manusia hanya sebagai objek hukum, tidak dapat digunakan lagi. Cara berpikir tersebut harus dilengkapi dengan cara berpikir yang lebih maju, seperti cara berpikir utilitarian, anti utilitarian, dan pragmatis. Cara berpikir utilitarian mengharuskan hukum memiliki fungsi untuk meraih kesejahteraan tertinggi bagi jumlah terbesar masyarakat. Cara berpikir anti-utilitarian mengharuskan keseimbangan antara hak masyarakat banyak dengan hak kelompok minoritas dalam masyarakat tersebut.

Analisis mengenai nilainilai keadilan menurut Aristotles menyatakan bahwa keadilan adalah kebajikan yang berkaitan dengan hubungan antar manusia. ${ }^{7}$ Keadilan sosial sudah merupakan sebuah wacana dan program untuk memajukan pendidikan hukum.

6 Sudikno Mertokusumo, 2007, Mengenal Hukum (Suatu Pengantar), Cetakan ke- 3, Liberty, Yogjakarta, hlm. 8.

7 Darji Darmodiharjo \& Shidarta, 2006, PokokPokok Filsafat Hukum, PT Gramedia Pustaka Utama, Jakarta, hlm. 156.
Pembentukan peraturan informasi dan transaksi elektronik adalah salah satu langkah untuk membuat pendidikan hukum mendekatkan diri dengan keadilan sosial. Keadilan sosial lebih menekankan kepada kebutuhankebutuhan masyarakat (needs), dibandingkan dengan keinginan masyarakat (wants of the society. Keadilan sosial lebih dekat dengan makna keadilan komutatif, keadilan atas dasar persamaan (equity) tanpa melihat jasa seseorang, bahkan juga tidak melihat status sosial, ekonomi dan politik seseorang. Peraturan Perundang undangan yang baik mutlak menjunjung tinggi prinsip keadilan. Dalam metodologi pembentukan hukum sekarang ini, teknik perundangundangan menempati posisi sentral. Sebab suatu teknik perundangundangan yang baik seharusnya mampu mencegah banyak masalahmasalah interpretasi. ${ }^{8}$

Pada intinya secara substansial antara filsafat hukum, ilmu hukum, dan teori hukum itu saling berkaitan tetapi juga berbeda. Filsafat hukum memiliki ruang lingkup lebih luas karena di dalam filsafat hukum memuat teori hukum, tujuan hukum, dan manfaat hukum. Sedangkan teori hukum hanya bersifat memberikan penjelasan tentang sebuah fenomena hukum atau fakta hukum. Ruang lingkupnya lebih sempit dan tidak terlalu mendasar.

\footnotetext{
Gagah Sujadmiko, 2011, Pengaturan dana Alokasi Khusus Dalam Hubungan keuangan Pusat Dan Daerah, (Tesis) Program Studi Magister (S2) Ilmu Hukum Pascarjana Universitas Udayana, Denpasar, hlm. 91.
} 
Sedangkan ilmu hukum memberi penekanan pada substansi (isi) yang bentuknya normati dari hukum sebagai hasil implementasi dari aspeknya yang teknis prosedural. ${ }^{9}$

Dalam pengembanan hukum teoritikal, ilmu hukum dogmatik yang paling relevan untuk pembentukan hukum dan penemuan hukum. Dimana ilmu hukum dogmatik ini mengarahkan kita pada kegiatan memaparkan, menganalisis, mensistematisasi dan menginterpretasi hukum positif yang berlaku. Sedangkan untuk pengembangan hukum praktikal Teori hukum yang memiliki tugas untuk mempelajari makna dan struktur dari pembentukan hukum dan penemuan hukum. Untuk filsafat hukum, tugasnya adalah merefleksi semua masalah fundamental yang berkaitan dengan hukum, tidak hanya hakikat dan metode dari ilmu hukum tetapi juga mengkritik pengaruh dari filsafat ilmu modern pada teori hukum. Filsafat hukum bergerak lebih jauh dan merefleksi persoalan keadilan, yang bagi teori hukum merupakan pertanyaan yang tidak relevan.

Hukum merupakan suatu kaidah yang bertujuan untuk memenuhi kebutuhan dasar manusia pada segala tingkatan yang bertujuan untuk mencapai kedamaian dalam masyarakat. Pada tatanan dogmatika hukum, Undang-Undang Republik Indonesia nomor 11 tahun 2008 tentang Informasi dan Transaksi Elektronik (selanjutnya disebut dengan UU ITE)

$9 \quad$ Ibid. adalah jawaban terhadap pembangunan teknologi informasi di Indonesia.

Berdasarkan Pasal 1 UU ITE, pengertian transaksi elektronik adalah perbuatan hukum yang dilakukan dengan menggunakan Komputer, jaringan Komputer, dan/atau media elektronik lainnya. Transaksi elektronik berkaitan dengan sistem pembayaran yaitu menyangkut tata cara pembayaran barang ataupun jasa yang akan dibeli yang dapat dilakukan secara tunai maupun kredit. Sedangkan alat pembayaran yang dipilih dapat berbentuk tunai (uang kartal) maupun non-tunai (uang giral).

\subsection{Bentuk-Bentuk Tanda Tangan yang Sah Digunakan dalam Transaksi Elektronik di Indonesia}

Perkembangan penting sebagai akibat dari kemajuan teknologi informasi khususnya internet adalah semakin meningkatnya transaksi dagang yang mengunakan fasilitas ini. Transaksi dagang tidak lagi dilakukan secara tradisional, tidak lagi terbatas oleh wilayah, dan dilakukan tanpa melalui dokumen tertulis (scriptless). Transaksi dewasa ini dapat terjadi pada saat bersama tanpa harus bertemu dan dilakukan secara cepat. ${ }^{10}$ Dengan perdagangan lewat internet, berkembang pula sistem bisnis virtual, seperti virtual store dan virtual company, dimana pelaku bisnis

10 Huala Adolf, 2006, Dasar-dasar Hukum Kontrak Internasional, Refika Aditama, 2006, hlm. 39. 
menjalankan bisnis dan perdagangan melalui media internet dan tidak lagi mengandalkan basis perusahaan yang konvensional nyata. ${ }^{11}$

Dalam Burgerlijk Wetboek (yang telah diterjemahkan menjadi Kitab Undang-Undang Hukum Perdata), terdapat adanya suatu pengakuan terhadap surat yang bertandatangan, sedangkan surat yang tidak bertandatangan tidak diakui karena tidak dapat diketahui siapa pemiliknya. Surat yang telah bertandatangan dibuat untuk dipakai sebagai alat bukti dan nantinya dipergunakan untuk keperluan suatu transaksi.

Pasal 11 UU ITE telah menegaskan bahwa transaksi elektronik yang dituangkan dalam kontrak elektronik mengikat para pihak yang menimbulkan hak dan kewajiban bagi masing-masing pihak, asalkan ditandatangani secara elektronik oleh para pihak sesuai dengan ketentuan perundang-undangan yang berlaku. Maka dapat ditarik suatu pernyataan bahwa seluruh transaksi elektronik dengan tanda tangan elektronik dapat dianggap sebagai akta, bahkan kekuatan pembuktiannya sama seperti akta. Berdasarkan Pasal 1 angka 12 UU ITE disebutkan bahwa "Tanda Tangan Elektronik adalah tanda tangan yang terdiri atas Informasi Elektronik yang dilekatkan, terasosiasi atau terkait dengan Informasi Elektronik lainnya

11 Asril Sitompul, 2004, Perdagangan Elektronik, Cetakan ke IX, Citra Aditya Bakti, Bandung, hlm.4. yang digunakan sebagai alat verifikasi dan autentikasi."

Mengenai bentuk tanda tangan elektronik, terdapat beberapa mode teknologi terhadap bentuk-bentuk dari suatu Tanda Tangan Elektronik (digital signature), yakni:

1. Penggunaan kata kunci (password) ataupun kombinasinya (hybrid methods);

2. Tanda tangan yang dipindai secara elektronik (scanned signature) atau pengetikan nama pada suatu informasi (typed names);

3. Penggunaan fitur tombol tanda persetujuan atau tanda penerimaan secara elektronik (ok button atau accept button) yang ditunjang dengan saluran komunikasi yang aman (secured socket layer);

4. Penggunaan tanda yang unik pada anggota badan (biometric);

5. Penggunaan Tanda Tangan Elektronik yang berbasiskan enkripsi suatu pesan (digital signature). ${ }^{12}$

Selanjutnya, pada Pasal 1 angka 19 Peraturan Pemerintah Republik Indonesia nomor 82 tahun 2012 tentang Penyelenggaraan Sistem dan Transaksi Elektronik (selanjutnya disebut PP 82/2012), disebutkan bahwa Tanda Tangan Elektronik adalah tanda tangan yang terdiri atas Informasi Elektronik yang dilekatkan, terasosiasi atau terkait

\footnotetext{
12 Edmon Makarim, 2011, Notaris dan Tanda Tangan Elektronik, Cet. I, PT. Rajawali Grafindo Persada, Jakarta, hlm. 44.
} 
dengan Informasi Elektronik lainnya yang digunakan sebagai alat verifikasi dan autentikasi. Tanda Tangan Elektronik memiliki karakteristik atau sifat yaitu:

1. Autentik, dapat dijadikan alat bukti di pengadilan (sempurna);

2. Hanya sah untuk dokumen atau pesan itu saja atau copynya. Dokumen berubah satu titik saja, tanda tangan jadi invalid;

3. Dapat diperiksa dengan mudah oleh siapapun, bahkan oleh orang yang belum pernah bertemu (dengan sertifikat elektronik tentunya).

Ketentuan-ketentuan lain yang mengatur mengenai proses penandatangan pada transaksi elektronik yang terkait dengan penggunaan Tanda Tangan Elektronik dalam transaksi tersebut telah diatur dalam Pasal 52 - 58 PP 82/2012 dimana:

1. Pada Pasal 52 dan Pasal 53 PP $82 / 2012$ menjelaskan mengenai penjelasan umum tentang tanda tangan elektronik.

2. Pada Pasal 54 PP 82/2012 mengatur mengenai jenis-jenis tanda tangan elektronik yang terbagi menjadi tanda tangan elektronik tersertifikasi dan tanda tangan elektronik tidak tersertifikasi.

3. Pada Pasal 55 PP $82 / 2012$ mengatur mengenai data pembuatan tanda tangan elektronik.
Pada Pasal 56 PP 82/2012 mengatur mengenai proses penandatanganan dalam transaksi elektronik.

\section{PENUTUP}

\subsection{Simpulan}

1. Dalam melakukan suatu transaksi elektronik diperlukan sesuatu yang berlaku selayaknya tanda tangan pada transaksi yang berbasis kertas yaitu yang dalam UU ITE disebut tanda tangan elektronik.

2. Bentuk- bentuk dari tanda tangan elektronik tersebut adalah dapat berupa penggunaan kata kunci (password) ataupun kombinasinya (hybrid methods); tanda tangan yang dipindai secara elektronik (scanned signature) atau pengetikan nama pada suatu informasi (typed names); penggunaan fitur tombol tanda persetujuan atau tanda penerimaan secara elektronik (ok button atau accept button) yang ditunjang dengan saluran komunikasi yang aman (secured socket layer); penggunaan tanda yang unik pada anggota badan (biometric); penggunaan tanda tangan elektronik yang berbasiskan enkripsi suatu pesan (digital signature).

\subsection{Saran}

1. Pengaturan transaksi elektronik harus diatur dalam aturan yang 
bersifat teknis karena sesuai dengan kebutuhan praktik yang semakin berkembang di jaman globalisasi sehingga kekosongan hukum terkait dengan transaksi elektronik tidak terjadi.

2. Klasifikasi bentuk bentuk tanda tangan elektronik wajib diatur dalam peraturan perundanganundangan yang lebih konkrit karena pengaturan yang saat ini mengakomodir bentukbentuk tanda tangan elektronik masih bersifat umum dan tidak mengkhusus.

\section{DAFTAR PUSTAKA}

\section{Buku}

Adolf, Huala, 2006, Dasar-dasar Hukum Kontrak Internasional, Refika Aditama.

Amiruddin dan Asikin, Zainal 2004, Pengantar Metode Penelitian Hukum, PT. Raja Grafindo Persada, Jakarta.

Darmodiharjo, Darji, \& Shidarta, 2006, Pokok-Pokok Filsafat Hukum, PT Gramedia Pustaka Utama, Jakarta.

Darus Badrulzaman, Mariam, 2001, Mendambakan Kelahiran Hukum Saiber (Cyber Law) di Indonesia, Purna Bhakti, Medan.

Edmon, 2011, Notaris dan Tanda Tangan Elektronik, Cet. I, PT. Rajawali Grafindo Persada, Jakarta.
Arief Sidharta, 2007, Meuwissen, tentang Pengembangan Hukum, Ilmu hukum, teori hukum, Filsafat Hukum, Refika Aditama, Bandung

Sitompul, Asril, 2004, Perdagangan Elektronik, Citra Aditya Bakti, Bandung.

Soekanto, Soerjono dan R. Otje Salman, Otje, 1987, Disiplin Hukum dan Disiplin Sosial, Rajawali Pers, Jakarta.

Sudikno Mertokusumo, 2007, Mengenal Hukum (Suatu Pengantar), Cetakan ke- 3, Liberty, Yogjakarta.

Sunggono, Bambang 2010, Metodologi Penelitian Hukum, Rajawali Pers, Jakarta.

\section{Artikel/Makalah/Tesis}

Gagah Sujadmiko, 2011, Pengaturan dana Alokasi Khusus Dalam Hubungan keuangan Pusat Dan Daerah, (Tesis) Program Studi Magister (S2) Ilmu Hukum Pascarjana Universitas Udayana, Denpasar

Ladjin, Nurjanna, 2008, “Analisis Kemandirian Fiskal Di Era Otonomi Daerah (Studi Kasus Di Propinsi Sulawesi Tengah)", (Tesis) Program Studi Magister (S2) Ilmu ekonomi dan Studi Pembangunan Pascarjana Universitas Diponegoro, Semarang. 


\section{Perundang-undangan}

Burgerlijk Wetboek, penerjemah:

Subekti, Raden dan R.

Tjitrosudibio, 2001, Kitab

Undang-Undang Hukum

Perdata, Cetakan XXXI (edisi

revisi), PT. Pradnya Paramita, Jakarta.

Undang-Undang Republik Indonesia nomor 11 tahun 2008 tentang Informasi dan Transaksi Elektronik

Peraturan Pemerintah Republik Indonesia nomor 82 tahun 2012 tentang Penyelenggaraan Sistem dan Transaksi Elektronik 